
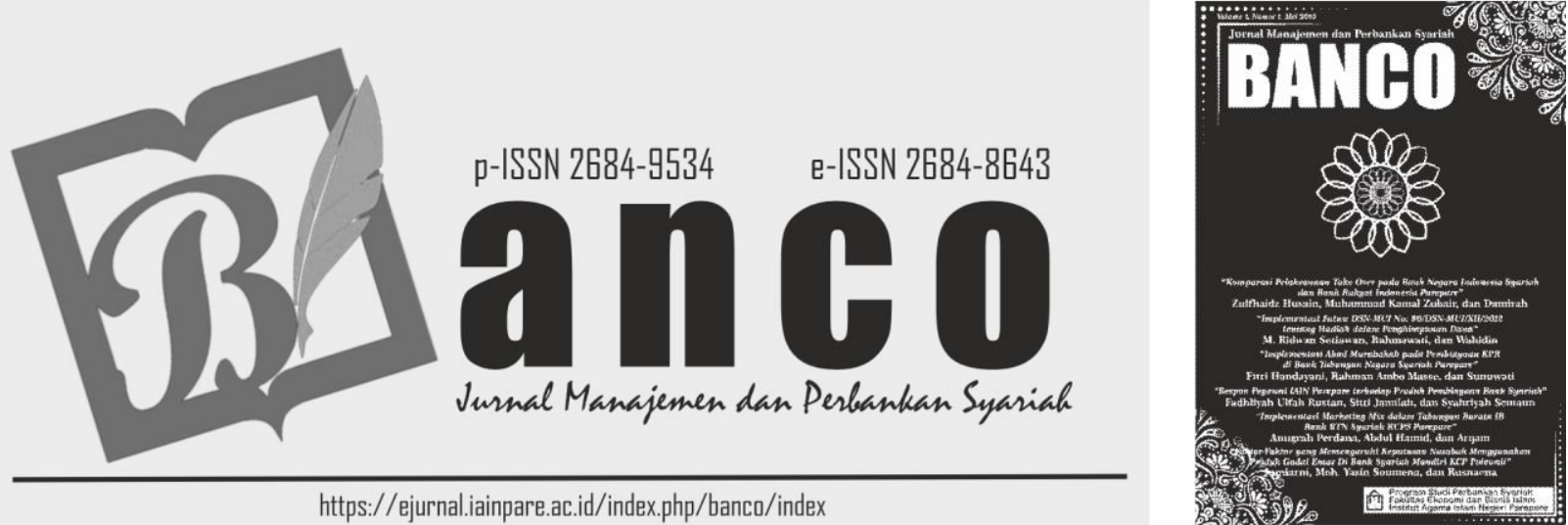

https://ejurnal.iainpare.ac.id/index.php/banco/index

\title{
PENGAWASAN DAN PEMBINAAN PEMBIAYAAN \\ MURABAHAH BERMASALAH DI KSPPS BMT HUSNUL AULIA \\ CILEDUG
}

Siti Fatimah

IAIN Syekh Nurjati Cirebon

Sitif8352@gmail.com

Toto Suharto

IAIN Syekh Nurjati Cirebon

\begin{abstract}
This study aims to determine the implementation of supervision and fostering problematic murabaha financing at BMT Husnul Aulia Ciledug. This study uses qualitative research with data collection methods using interviews, observation and documentation and then analyzed using descriptive analysis. The results of this study: the implementation of preventive supervision of murabaha financing in BMT Husnul Aulia namely by carrying out administrative supervision namely checking all required documents and applying the principle of $6 \mathrm{C}$ in the analysis of financing, while the implementation of repressive supervision of murabaha financing is problematic by carrying out direct supervision of visiting places businesses of BMT members routinely and carry out indirect supervision, namely nominative checks. In addition to supervision, BMT Husnul Aulia conducts coaching that is by visiting the place of business or residence and providing input and solutions to problems that are being faced in the business so that financing problems arise.
\end{abstract}

Keywords: Supervision, Guidance, Murababa, Problem Funding. 


\title{
Siti Fatimah dan Toto Suharto
}

\begin{abstract}
Abstrak
Penelitian ini bertujuan untuk mengetahui pelaksanaan pengawasan dan pembinaan pembiayaan murabahah bermasalah di BMT Husnul Aulia Ciledug. Penelitian ini menggunakan penelitian kualitatif dengan metode pengumpulan data menggunakan wawancara, observasi dan dokumentasi kemudian dianalisis menggunakan deskriptif analisis. Adapun hasil dari penelitian ini: pelaksanaan pengawasan preventif pembiayaan murabahah di BMT Husnul Aulia yaitu dengan melakukan pengawasan secara administratif yaitu pengecekan terhadap semua berkas persyaratan dan menerapkan prinsip 6C dalam analisis pembiayaan, sedangkan pelaksanaan pengawasan represif pada pembiayaan murabahah bermasalah yaitu dengan melakukan pengawasan langsung mendatangi tempat usaha anggota BMT secara rutin dan melakukan pengawasan tidak langsung yaitu cekling nominatif. Selain pengawasan, BMT HusnulAulia melakukan pembinaan yaitu dengan mendatangi tempat usaha atau kediamannya dan memberikan masukan serta solusi atas masalah yang sedang dihadapi dalam usahanya sehingga timbul pembiayaan bermasalah
\end{abstract}

Kata kunci : Pengawasan, Pembinaan, Murabahah, Pembiayaan Bermasalah

\section{A. Pendahuluan}

Pada dasarnya setiap aktivitas yang dilakukan oleh manusia di dunia ini selalu berkaitan dengan masalah perekonomian. Perekonomian yang terjadi didalam masyarakat tidak terlepas dari adanya peran suatu lembaga keuangan. Jumlah lembaga keuangan di Indonesia selalu mengalami peningkatan dari tahun ke tahun. Menurut pasal 1 UU No.14 Tahun 1967 dan diganti dengan UU No. 7 Tahun 1992 yang membahas tentang perbankan di Indonesia menyatakan bahwa lembaga keuangan adalah badan atau lembaga yang kegiatannya menarik hasil dana dari masyarakat dan kemudian menyalurkannya kepada masyarakat kembali.(Wahyu \& Anwar, 2020)

Lembaga Keuangan Mikro Syariah (LKMS) merupakan salah satu lembaga keuangan mikro yang dalam menjalankan usahanya berdasarkan prinsip syariah. Lembaga Keuangan Mikro berdasarkan Undang-Undang Nomor 1 Tahun 2013 tentang Lembaga Keuangan Mikro didefinisikan sebagai lembaga keuangan yang khusus didirikan untuk memberikan jasa pengembangan usaha dan pemberdayaan masyarakat, baik melalui pinjaman atau pembiayaan dalam usaha skala mikro kepada anggota dan masyarakat, pengelolaan simpanan, maupun pemberian jasa konsultasi pengembangan usaha yang tidak semata-mata mencari keuntungan.(Falihah et al., 2020)

Lembaga Keuangan Mikro ini memberikan jasa layanan keuangan kepada masyarakat khususnya masyarakat golongan menengah kebawah. Dengan adanya peran dari LKM ini masyarakat tidak lagi kesulitan terkait kondisi ekonomi. LKM ini sangat membantu masyarakat yang mayoritas memiliki pendapatannya menengah kebawah. Selain adanya lembaga keuangan mikro konvensional, saat ini telah muncul lembaga keuangan mikro syariah. Lembaga keuangan mikro syariah dijalankan berdasarkan prisip syariah. Eksistensi lembaga keuangan mikro syariah tak kalah dengan lembaga keuangan lain.

Baitul Maal Wat Tamwil (BMT) termasuk salah satu lembaga keuangan mikro syariah. BMT merupakan lembaga yang didirikan berdasarkan prinsip syariah. Baitul Maal Wat Tamwil (BMT) berperan penting karena dapat membantu memenuhi keinginan sebagian kalangan masyarakat khususnya umat muslim yang menginginkan jasa layanan lembaga keuangan untuk mengelola perekonomiannya sesuai dengan ketentuan syariah. Lembaga ini didirikan dengan maksud untuk memfasilitasi masyarakat bawah yang tidak terjangkau oleh pelayanan bank Islam atau BPR Islam. Prinsip operasional BMT didasarkan atas prinsip bagi hasil (profit and loss sharing), serta tidak menggunakan bunga sebagai alat untuk memperoleh pendapatan karena bunga merupakan riba yang diharamkan. Selain itu, BMT adalah lembaga keuangan yang operasional dan produknya dikembangkan berdasarkan Al-Qur'an dan Hadits Nabi Muhammad SAW.(Harahap \& Ghozali, 2020)

Segmentasi dari Lembaga Keuangan Non-Bank dalam hal ini BMT yaitu masyarakat atau pengusaha sektor riil dan mikro yang membutuhkan fasilitas pembiayaan dalam skala kecil untuk membiayai usaha yang dijalankannya. Selain itu BMT juga berperan dalam membantu masyarakat yang memiliki kelebihan dana namun 
tidak memiliki usaha. Keberadaan BMT ditengah-tengah masyarakat ini diharapkan dapat membantu memenuhi kebutuhan masyarakat kecil dan mensejahterakannya terutama di sekitar tempat berdirinya.

KSPPS BMT Husnul Aulia merupakan salah satu BMT yang terletak di Kabupaten Cirebon tepatnya di Desa Jatiseeng Kidul Kecamatan Ciledug. BMT Husnul Aulia ini baru memiliki satu tempat operasional. Dalam menjalankan operasionalnya, KSPPS BMT Husnul Aulia menyediakan berbagai macam produk simpanan dan pembiayaan. Salah satu fasilitas yang disediakannya yaitu pembiayaan. Pembiayaan berdasarkan prinsip syariah yang termuat dalam UU No.10 tahun 1998 tentang perbankan adalah penyediaan uang atau tagihan yang dipersamakan dengan itu berdasarkan persetujuan atau kesepakatan antar bank dengan pihak lain yang mewajibkan pihak yang dibiayai untuk mengembalikan uang atau tagihan tersebut setelah jangka waktu tertentu dengan imbalan atau bagi hasil. (Harahap \& Ghozali, 2020)

Fasilitas pembiayaan merupakan aset terbesar di dalam lembaga keuangan karena dengan adanya pembiayaan BMT dapat mendapatkan profitabilitas (keuntungan) melalui penyaluran pembiayaan yang kemudian memperoleh bagi hasil dari usaha yang dikelola oleh anggota BMT itu sendiri. Tabel berikut menunjukkan data pertumbuhan pembiayaan di BMT Husnul Aulia periode tahun 2016-2018:

Tabel 1.1

Pertumbuhan Pembiayaan BMT Husnul Aulia Periode Tahun 2016-2018

\begin{tabular}{|c|c|c|}
\hline Tahun & Pembiayaan yang Diterima & Pembiayaan yang Diberikan \\
\hline 2016 & 454.247 .661 & 4.026 .094 .100 \\
\hline 2017 & 184.151 .040 & 4.689 .066 .584 \\
\hline 2018 & 49.598 .718 & 6.078 .842 .815 \\
\hline
\end{tabular}

Sumber : KSPPS BMT Husnul Aulia

Dari tabel tersebut dapat diketahui bahwa pertumbuhan pembiayaan yang diterima oleh KSPPS BMT Husnul Aulia mengalami penurunan. Sedangkan pembiayaan yang diberikan oleh BMT Husnul Aulia dari tahun ketahun selalu mengalami peningkatan. Dari adanya peningkatan pembiayaan tersebut, pihak BMT Husnul Aulia harus menerima risiko yang ditimbulkannya. Risiko yang dihadapi oleh BMT Husnul Aulia salah satunya yaitu permasalahan dalam tingkat kelancaran pengembalian pembiayaan yang diberikan atau yang biasa dikenal dengan pembiayaan bermasalah. Suatu lembaga keuangan dikatakan sehat apabila tidak terdapat permasalahan keuangan seperti jumlah yang dikembalikan nasabah pada saat pengajuan pembiayaan harus setara dengan jumlah pembiayaan yang diberikan BMT.

Pembiayaan bermasalah atau Non Perfoming Finance (NPF) adalah pembiayaan yang dalam kualitasnya berada dalam golongan kurang lancar (III), diragukan (golongan IV) dan macet (golongan V). Pembiayaan bermasalah ini merupakan permasalahan yang umum terjadi di lembaga keuangan. Karena tidak semua orang memiliki kelancaran dalam menjalankan usahanya, sehingga terjadi penunggakan dalam pengembaliannya.(Ulpah, 2020)

Di BMT Husnul Aulia sendiri produk pembiayaan yang terdapat permasalahan yaitu terjadi pada produk pembiayaan murabahah. Pembiayaan murabahah merupakan produk pembiayaan yang paling unggul diantara produk pembiayaan lainnya. Alasanya, produk pembiayaan murabahah ini prosedurnya mudah dibanding 
produk lain. Selain itu, masyarakat disekitar BMT Husnul Aulia berprofesi sebagai pedagang. Adapun data terkait piutang murabahah bermasalah:

Tabel 1.2

Kolektabilitas Pembiayaan Murabahah

\begin{tabular}{|c|c|c|c|}
\hline \multirow{2}{*}{ Kolektabilitas } & \multicolumn{3}{|c|}{ Tahun } \\
\cline { 2 - 4 } & $\mathbf{2 0 1 6}$ & $\mathbf{2 0 1 7}$ & $\mathbf{2 0 1 8}$ \\
\hline Lancar & 3.615 .432 .605 & 4.349 .505 .584 & 5.026 .178 .388 \\
\hline Kurang lancar & 113.852 .790 & 42.649 .000 & 159.985 .537 \\
\hline Diragukan & 93.034 .418 & 48.200 .000 & 133.380 .000 \\
\hline Macet & 203.774 .390 & 139.413 .000 & 279.975 .990 \\
\hline Total & 4.026 .094 .100 & 4.689 .066 .584 & 6.078 .842 .815 \\
\hline NPF & $10.2 \%$ & $5 \%$ & $10 \%$ \\
\hline
\end{tabular}

Sumber : KSPPS BMT Husnul Aulia

Tabel 1.2 diatas menunjukkan data keuangan pembiayaan murababah bermasalah di BMT Husnul Aulia. Dilihat dari persentase NPF pada pembiayaan murabahah periode tahun 2016 sampai dengan 2018 mengalami naik turun. Pada tahun 2016 nilai NPF sebesar 10.2\%, sedangkan pada tahun 2017 nilai NPF mengalami penurunan yaitu sebesar 5\% yang artinya NPF di BMT Husnul Aulia sudah memenuhi standar NPF. Namun, pada tahun 2018 Nilai NPF kembali mengalami kenaikan yang cukup drastis yaitu sebesar 10\%. Dengan demikian dapat disimpulkan bahwa nilai NPF (Non Perfoming Finance) pembiayaan murabahah KSPPS BMT Husnul Aulia mengalami naik turun setiap tahunnya.

Dari tabel tersebut menunjukkan persentase NPF dari tahun ke tahun mengalami naik turun, maka BMT mempunyai strategi dalam mengatasi permasalahan yang dihadapinya. Upaya yang dilakukan BMT salah satunya yaitu dengan melakukan pengawasan dan pembinaan pembiayaan kepada anggotanya. Pengawasan pembiayaan diartikan sebagai salah satu fungsi manajemen yang berupaya untuk menjaga dan mengamankan pembiayaan itu sebagai kekayaan dan dapat mengetahui term of lending serta asuransi-asuransi sebagai dasar persetujuan pembiayaan tercapai atau terjadinya penyimpangan. Sedangkan pembinaan adalah usaha, tindakan dan kegiatan yang dilakukan secara berdaya guna dan berhasil guna untuk memperoleh hasil yang lebih baik.(Ulpah, 2020)

Pengawasan merupakan langkah awal BMT dalam memberikan pembiayaan kepada anggota. Tidak hanya itu pengawasan juga meliputi pengawasan sebelum pembiayaan diberikan (steering control), pengawasan pada waktu proses persetujuan pembiayaan (post action control) dan pengawasan setelah pembiayaan diberikan (feedback control)(Cicik Mutiah et al., 2020). Ketika terjadi pembiayaan bermasalah BMT melakukan pembinaan kepada anggota pembiayaan guna memperbaiki pembiayaan bermasalah. Pengawasan dan pembinaan pembiayaan ini mempunyai keterkaitan satu dengan lainnya yang pada intinya bertujuan sebagai tindakan pencegahan dini dan penjagaan terhadap aset perusahaan. Apabila fungsi pengawasan dan pembinaan dilakukan secara efektif hal itu dapat meminimalisir pembiayaan bermasalah, sebaliknya jika masih terdapat pembiayaan bermasalah berarti fungsi pengawasan dan pembinaan ini tidak dijalankan secara efektif. (Prastiwi, 2021)

Dari uraian latar belakang diatas dengan adanya permasalahan tersbut, maka penelitian ini bertujuan mengurai "Pelaksanaan Pengawasan dan Pembinaan pada Pembiayaan Murabahah Bermasalah di KSPPS BMT Husnul Aulia Ciledug”..

\section{B. Diskusi dan Pembahasan}

1. Pelaksanaan Pengawasan Preventif pada Pembiayaan Murabahah Bermasalah di BMT Husnul Aulia Ciledug 
Setiap lembaga keuangan baik lembaga keuangan syariah atau lembaga keuangan konvensional dalam menjalankan operasionalnya memiliki tiga fungsi yaitu sebagai penghimpun dana, penyalur dana dan pelayanan jasa. Lembaga keuangan syariah melakukan penghimpunan dana melalui simpanan sedangkan penyaluran dana dalam bentuk pembiayaan. Salah satu produk pembiayaan yang ada di BMT Husnul Aulia Ciledug yaitu pembiayaan murabahah. Pembiayaan murabahah yaitu akad jual beli antara bank dengan nasabah, dimana bank bertindak sebagai penjual dan nasabah bertindak sebagai pembeli. (Muhlis, 2020)

Adapun prosedur pengajuan pembiayaan murabahah yang terdapat di BMT Husnul Aulia adalah sebagai berikut:

a. Calon anggota pembiayaan murabahah mendatangi BMT Husnul Aulia Ciledug untuk pengajuan

pembiayaan dan melakukan wawancara dengan bagian Costumer Service mengenai tujuan pembiayaan dan plafond pembiayaan.

b. Mengisi form pengajuan dan permohonan pembiayaan dengan melengkapi persyaratan yang dibutuhkan. Persyaratan pengajuan pembiayaan murabahah tersebut ialah:

c. Mengisi formulir pengajuan pembiayaan.

d. Fotocopy KTP suami dan Isteri.

e. Fotocopy kartu keluarga.

f. Jaminan berupa akta jual beli, sertifikat, BPKB (minimal 5 tahun kebelakang) dan simpanan.

g. Bersedia di survei

BMT Husnul Aulia berhak menolak pengajuan pembiayaab tanpa pemberitahuan alasan.

Apabila persyaratan tersebut tidak lengkap, maka BMT Husnul Aulia meminta calon anggota pembiayaan untuk melengkapinya. Sedangkan apabila persyaratan tersebut lengkap, maka AO melakukan survey dan analisis kelayakan dengan prinsip 5C.

Hasil survey tersebut kemudian diusulkan kedalam komite pembiayaan untuk memutuskan apakah layak atau tidak menerima pembiayaan murabahah tersebut.

Jika tidak layak maka admin pembiayaan BMT Husnul Aulia menghubungi calon anggota tersebut untuk mengembalikan dokumen-dokumen dan memberitahu alasan pengajuan tersebut ditolak. Sebaliknya, jika permohonan tersebut disetuji bagian admin pembiayaan konfirmasi kepada calon anggota untuk datang ke BMT Husnul Aulia Ciledug.

Saat ini pembiayaan murabahah yang terdapat di BMT Husnul Aulia Ciledug merupakan pembiayaan yang memiliki anggota terbanyak dibandingkan dengan pembiayaan lainnya. "Pembiayaan murabahah merupakan pembiayaan yang paling banyak diminati. Karena prosedur pembiayaan murabahah itu mudah tidak seperti pembiayaan yang lain"(Muhlis, 2020)

Selain itu ibu Zaitun menambahkan terkait pembiayaan murabahah: "Produk pembiayaan yang diminati yaitu murabahah. Karena pembiayaan murabahah itu paling simple. Jadi pengadaan barang dilakukan oleh BMT. Seperti pengadaan modal usaha dengan akad mudharabah kita buat menjadi akad murabahah BMT yang melakukan pengadaan barangnya seolah-olah itu jual beli’.(Tryana, 2021)

Tabel 4.1

Jumlah Nasabah Pembiayaan KSPPS BMT Husnul Aulia

Per 31 Desember 2018

\begin{tabular}{|c|c|}
\hline Pembiayaan & Jumlah Nasabah \\
\hline Pembiayaan Mudharabah & 1 \\
\hline
\end{tabular}




\begin{tabular}{|c|c|}
\hline Pembiayaan Musyarakah & 0 \\
\hline Pembiayaan Murabahah & 319 \\
\hline Pembiayaan Ijaroh & 26 \\
\hline Total & 346 \\
\hline
\end{tabular}

Sumber: KSPPS BMT Husnul Aulia

Berdasarkan tabel tersebut dapat disimpulkan bahwa pembiayaan yang paling banyak yaitu masih didominasi oleh pembiayaan murabahahhal ini dapat dilihat dari jumlah nasabah pada pembiayaan di BMT Husnul Aulia per 31 Desember 2018. Dengan meningkatnya jumlah pembiayaan murabahah, maka terdapat risiko yaitu pembiayaan bermasalah.

Adapun kolektabilitas atau penggolongan pembiayaan murabahah bermasalah di BMT Husnul Aulia sebagaimana yang dijelaskan oleh beberapa karyawan BMT Husnul Aulia.

Ibu Zaitun mengatakan, "pembiayaan murabahah juga kan ada kategorinya. Apabila tidak bayar selama 3 sampai 6 bulan dikategorikan kurang lancar, tidak bayar selama 6 sampai 9 bulan dikategorikan diragukan, sedangkan lebih dari 9 bulan dikategorikan macet atau bisa juga jika sudah jatuh tempo tetapi tidak bayar itu juga dinamakan macet".

Beberapa faktor penyebab terjadinya pembiayaan murabahah bermasalah di BMT Husnul Aulia. Faktor tersebut terdiri dari faktor internal dan faktor eksternal, diantaranya yaitu:

\section{a. Faktor Internal}

Faktor internal merupakan faktor yang berasal dari dalam BMT ataupun anggota BMT tersebut. Faktor internal penyebab pembiayaan murabahah bermasalah di BMT Husnul Aulia Ciledug adalah:

1) Kesalahan BMT dalam Menganalisis Pembiayaan yang Akan Diberikan

Sebelum memberikan pembiayaan kepada anggota yang akan mengajukan pembiayaan, pihak BMT melakukan analisa kelayakan terhadap pembiayaan yang akan diberikan apakah anggota tersebut berhak menerima pembiayaan atau tidak. Tujuan dilakukan analisa pembiayaan yaitu untuk menghindari terjadinya pembiayaan bermasalah. Jika analisa pembiayaan ini tidak dilakukan secara mendalam, maka akan terjadi adanya pembiayaan bermasalah. Kesalahan dalam menganalisis pembiayaan yaitu seperti adanya kesalahan terhadap data diri anggota BMT yang akan mengajukan pembiayaan.

2) Kurangnya Sumber Daya Manusia (SDM)

Terbatasnya jumlah SDM juga berpengaruh terhadap tingkat pembiayaan bermasalah karena jumlah anggota semakin tahun semakin bertambah namun SDM yang tersedia kurang mencukupi sehingga seluruh anggota tidak mendapatkan pengawasan dari pihak BMT.

\section{b. Faktor Eksternal}

Faktor eksternal merupakan faktor yang berasal dari luar BMT, faktor tesebut diantaranya yaitu:

Kondisi Usaha yang Tidak Stabil

Dalam menjalankan usaha, tidak selalu mendapatkan keuntungan. Hal ini juga salah satu penyebab terjadinya pembiayaan murabahah bermasalah di BMT Husnul Aulia, karena jika kondisi usaha yang dijalankan anggota menurun maka pendapatan juga akan menurun. Hal ini akan berdampak kepada pengembalian pembiayaan yang telah diberikan BMT. 
Seperti yang dikatakan oleh Bapak Anggi terkait faktor pembiayaan bermasalah: "Faktor-faktornya yaitu kalau di kita mah ada istilah bulan-bulan sepi dalam berjualan yang menyebabkan kondisi usahanya yang tidak stabil."

\section{1) Bencana Alam}

Salah satu faktor eksternal yang menyebabkan pembiayaan bermasalah juga terjadi karena adanya bencana alam seperti banjir, longsor, gempa bumi dan lain-lain.

Ibu Neli mengatakan, “ Tahun kemaren yaitu tahun 2018 daerah Cirebon Timur tepatnya didaerah Ciledug dan sekitarnya kan terjadi banjir ada yang gerobaknya rusak dagangannya terkena air banjir. Jadi anggota tersebut tidak punya penghasilan buat bayar angsuran"

\section{2) Karakter Anggota yang Buruk}

Penilaian terhadap karakter anggota juga penting dilakukan mengingat karakter setiap orang itu berbeda. Karakter anggota yang buruk menjadi penyebab timbulnya pembiayaan bermasalah. Karakter anggota juga dapat dilihat melalui struk tagihan seperti listrik, PDAM dan lain-lain. Hal ini dilakukan untuk mengetahui apakah dalam membayar tagihan tersebut tepat waktu atau tidak.

\section{3) Inflasi}

Ibu Zaitun mengatakan,"Faktor penyebab pembiayaan bermasalah juga kan berasal dari ekonomi makro yaitu inflasi. Inflasi tuh ketika nilai tukar rupiah turun, harga barang naik, minat masyarakat terhadap jual beli turun akhirnya terjadi ekonomi yang lesu. Dampaknya penghasilan anggota berkurang dan susah buat bayar hutang”.(Ghozali \& Roficoh, 2018)

Dalam memberikan pembiayaan kepada anggota yang akan mengajukan pembiayaan, pihak BMT tidak lepas tanggung jawab begitu saja melainkan tetap harus melakukan pengawasan kepada anggota yang menerima fasilitas pembiayaan murabahah tersebut. Pengawasan tersebut dilakukan pada saat sebelum dan sesudah pembiayaan diberikan kepada pemohon. Pengawasan sebelum realisasi pembiayaan disebut dengan pengawasan preventif, pengawasan preventif ini dimaksudkan untuk menjaga supaya tidak terjadi penyimpangan-penyimpangan yang dilakukan anggota yang menerima pembiayaan tersebut.(Sari et al., 2021)

Adapun pelaksanaan pengawasan preventif pada pembiayaan murabahah di BMT Husnul Aulia Ciledug diantaranya:

Pengawasan dengan melakukan pengecekan secara administratif. Seperti pengecekan terhadap berkas-berkas persyaratan yang harus dipenuhi oleh setiap calon anggota pembiayaan. Hal ini dilakukan sebagai penentu apakah calon anggota tersebut berhak menerima pembiayaan atau tidak.

Dilakukan analisis pembiayaan dengan menerapkan prinsip 6C sebagaimana yang tercantum dalam misi BMT Husnul Aulia. Analisis 6C tersebut yaitu:

\section{a. Character}

Character yaitu penilaian terhadap watak atau karakter anggota yang mengajukan permohonan. Penilaian terhadap karakter atau watak anggota ini bisa dilihat dari kejujurannya pada saat survey. Ibu Neli mengatakan:

"Penerapan prinsip 6C dilihat dari karakternya bagaimana, ketika survey kita melihat kalender yang ada dirumahnya tujuannya untuk mengetahui dia punya pinjaman dimana saja, cekling biasanya ke tetangga yaitu dua rumah dari depan, dua rumah dari belakang dan dua rumah dari samping baik kanan maupun kiri”. 


\section{b. Capacity}

Yaitu kemampuan anggota dalam membayar angsuran tiap bulannya. Penilaian ini dilihat dari usahanya apakah usaha tersebut berkembang atau tidak.

\section{c. Capital}

Yaitu modal yang dimiliki oleh anggota yang akan mengajukan pembiayaan. Sebagai tolak ukurnya, BMT menilai dengan melihat apakah modal untuk usahanya selalu berkembang atau sebaliknya.

\section{d. Collateral}

Collateral adalah jaminan yang sewaktu-waktu dapat diambil jika anggota tersebut tidak memenuhi kewajiban dalam mengembalikan pembiayaan yang telah diberikan. Jaminan yang terdapat di BMT Husnul Aulia dapat berupa BPKB kendaraan dan Sertifikat tanah atau bangunan.

\section{e. Condition of Economic}

Penilaian anggota harus mempertimbangkan kondisi ekonomi dari anggota tersebut. Apabila kondisi ekonomi anggota tersebut baik maka anggota tersebut berhak menerima pembiayaan, begitupun sebaliknya apabila kondisi ekonomi anggota tersebut buruk maka anggota tersebut tidak berhak menerima pembiayaan.

\section{f. Constrain}

Penilaian terhadap usaha yang dijalankannya. Apakah usaha tersebut dilarang ataupun tidak.Ibu Zaitun mengatakan, "Constraint tuh seperti usahanya tidak bathil atau tidak jelas. Percuma usahanya bagus tetapi jenis usahanya tidak baik maka tidak akan disalurkan pembiayaan, seperti ada kasus seseorang berpakaian rapih menggunakan hijab saat datang ke BMT untuk mengajukan permohonan tetapi kita tahu usaha orang tersebut yaitu prostitusi maka kita tidak jadi memberi pembiayaan".

\section{Pelaksanaan Pengawasan Represif pada Pembiayaan Murabahah Bermasalah di KSPPS BMT Husnul Aulia Ciledug}

Setelah pembiayaan tersebut terealisasipun pihak BMT Husnul Aulia Ciledug tetap melakukan pengawasan terhadap anggota tersebut. Pengawasan setelah pembiayaan terealisasi dinamakan dengan pengawasan represif. Pengawasan represif dimaksudkan untuk meminimalisir terhadap pembiayaan bermasalah. Pengawasan represifyang dilakukan BMT Husnul Aulia Ciledug yaitu dengan melalui :

Pengawasan setelah pembiayaan teralisasi di BMT Husnul Aulia yaitu dengan melakukan pengawasan secara tidak langsung kepada anggota pembiayaan, pengawasan tidak langsung diantaranya dengan melakukan pengecekan terhadap rekening anggota atau disebut dengan cekling nominatif. Melalui cekling nominatif ini maka dapat diketahui siapa saja yang sudah membayar atau yang belum membayar. (Nasution, 2021)

Ibu Neli mengatakan, “ sistem pengawasannya yaitu dengan melakukan cekling nominatif. Cekling nominatif ini di cek satu-satu siapa saja yang sudah masuk angsuran atau ada keterlambatan pada saat jatuh tempo. Pengawasan dengan cekling nominatif biasanya dilakukan di awal bulan sampai pertengahan bulan".

Pengawasan langsung pada pembiayaan murabahah yaitu dengan melakukan kunjungan secara rutin kepada tempat usaha atau kediaman anggota untuk melihat perkembangan usaha yang dijalankannya. (Lestari \& Jayanti, 2020) 
Abdul Ghofur mengatakan "Pengawasan langsung yang dilakukan di BMT HusnulAulia ini dengan melakukan kunjungan ke tempat usaha anggota tersebut. Kunjungan ini dilakukakn satu bulan sekali secara rutin oleh pihak AO per wilayah AO masing-masing."

\section{Pelaksanaan Pembinaan pada Pembiayaan Murabahah Bermasalah di BMT Husnul Aulia Ciledug}

Selain menjalankan fungsi manajemennya yaitu pengawasan, BMT Husnul Aulia juga melaksanakan pembinaan terhadap anggota pembiayaan murabahah bermasalah. Pengawasan ini tidak dapat berjalan dengan baik tanpa adanya pembinaan.

BMT Husnul Aulia Ciledug melakukan pembinaan kepada anggota pembiayaan murabahah bermasalah dengan cara: (Latif, 2020)

Pertama, mengunjungi tempat usaha atau kediaman anggota pembiayaan murabahah bermasalah. Dengan mengunjungi anggota tersebut pihak Account Officer melakukan wawancara dengan anggota terkait masalah yang sedang dihadapi oleh usahanya sehingga terjadi pembiayaan bermasalah.

Kedua, melakukan wawancara dan menemukan masalah yang sedang dihadapinya, maka pihak BMT melakukan pendampingan dengan cara memberikan solusi atau jalan keluar bersama-sama atas permasalahan pembiayaan bermasalah. Dalam hal ini BMT berperan sebagai konsultan. BMT memberikan solusi kepada anggota pembiayaan bermasalahnya dengan menawarkan kemampuan anggota dalam mengembalikan pembiayaan murabahah tersebut.

Ketiga, setelahanggota pembiayaan murabahah bermasalah menyetujui terkait kemampuan dalam membayarnya maka pihak BMT melakukan penagihan secara intensif.

Selain BMT Husnul Aulia melakukan pelaksanaan dan pembinaan pada pembiayaan murabahah bermasalah, BMT Husnul Aulia juga melakukan restrukturisasi pembiayaan untuk menangani pembiayaan murabahah bermasalah. Langkah-langkahnya yaitu :

\section{a. Penagihan secara Intensif}

Setelah BMT Husnul Aulia mengetahui bahwa anggota tersebut dikategorikan menjadi anggota pembiayaan bermasalah, maka BMT melakukan penagihan secara intensif terhadap anggotanya baik dengan melakukan kunjungan ke tempat usahanya ataupun di tempat kediamannya atau bisa juga melalui alat maupun media komunikasi seperti telepon dan sebagainya.

\section{b. Surat Teguran}

Selain itu, BMT Husnul Aulia juga memberikan surat peringatan kepada anggota pembiayaan bermasalah. Surat tersebut terdiri dari 3 jenis diantaranya surat peringatan I, surat peringatan II dan surat peringatan III. Jarak antara pemberian surat peringatan pertama sampai selanjutnya yaitu sekitar 6 bulan, namun apabila anggota tersebut tidak ada i'tikad baik maka jarak surat peringatannya bisa 3 bulan.

\section{c. Rescheduling}

Rescheduling merupakan salah satu penyelesaian pembiayaan bermasalah dengan penjadwalan ulang kembali baik jumlah angsuran maupun jangka waktu jatuh tempo.

Hasil wawancara dengan Pak. Anggi mengatakan, "kita selesaikan dengan rescheduling, jadi kita totalkan dulu berapa jumlah margin dan pokoknya terus kita jumlabkan terus dibagi jangka waktu. Contohnya margin Rp 4.000.000, pokok Rp 10.000.000, kemudian anggota tersebut memiliki kemampuan Rp 300.000 dalam sebulan. Maka Rp 4.000.000+Rp 10.000.000 = Rp 14.000.000. Kemudian Rp 14.000.000 $: \mathrm{R} p 300.000=46$ bulan. 
Jadi anggota harus membayar angsuran sebesar Rp 300.000 selama 46 bulan. Tapi, kita usahakan maksimal 36 bulan."

\section{d. Penyisihan Penghapusan Atktiva Produktif ( PPAP)}

BMT menutupi pembiayaan bermasalah dengan menggunakan dana cadangan yaitu PPAP. Menurut Ibu Zaitun "PP AP ini maksimal 2\%. Dengan rincian 1\% dari realisasi dan 1\% dari landing"

\section{Analisis Pelaksanaan Pengawasan dan Pembinaan Pembiayaan Murabahah Bermasalah Di KSPPS BMT Husnul Aulia Ciledug}

Pembiayaan adalah penyediaan uang atau tagihan yang dipersamakan dengan itu, berdasarkan persetujuan atau kesepakatan antara Bank dengan pihak lain yang mewajibkan pihak yang dibiayai untuk mengembalikan uang atau tagihan tersebut setelah jangka waktu tertentu dengan imbalan atau bagi hasil.

Secara umum prosedur pemberian pembiayaan pada BMT Husnul Aulia Ciledug selaras dengan teori yang dikemukakan oleh Kasmir oleh Badan Hukum yaitu : 1) pengajuan berkas-berkas, 2) penyelidikan berkas pinjaman, 3) wawancara I, 4) on the spot, 5) wawancara II, 6) keputusan kredit, 7) penandatanganan akad/ perjanjian lainnya, 8) realisasi kredit dan 9) penyaluran dana.

Salah satu produk pembiayaan yaitu pembiayaan murabahah, dimana pembiayaan murabahah ini ialah akad jual beli antara BMT dengan Anggota. BMT bertindak sebagai penjual karena pengadaan barangnya dilakukan oleh BMT, sedangkan anggota bertindak sebagai pembeli dengan ketentuan margin yang telah disepakati. (Taslim, 2021)

Saat ini pembiayaan murabahah merupakan pembiayaan yang masih banyak diminati oleh kalangan masyarakat. Alasannya tak lain karena terdapat kemudahan-kemudahan dalam pembiayaan murabahah seperti kemudahan dalam prosedurnya maupun kemudahan dalam marginnya. Karena pembiayaan murabahah ini merupakan pembiayaan yang paling diminati maka BMT harus siap menerima risikonya. Hal tersebut sesuai dengan teori dari Veithzal Rivai dan Arifin yang menyatakan bahwa dengan meningkatnya produk pembiayaan dalam Bank Syariah maka akan mendatangkan risiko pembiayaan yang besar pula, hal ini dikarenakan pembiayaan merupakan produk investasi Bank Syariah yang termasuk dalam produk Natural Uncertainty Contracts. (Anugrah, 2020)

Salah satu risiko pembiayaan murabahah adalah pembiayaan bermasalah. Pembiayaan bermasalah muncul dikarenakan adanya faktor-faktor penyebab munculnya pembiayaan bermasalah. Secara teori, faktor penyebab pembiayaan bermasalah digolongkan menjadi dua, yaitu faktor internal dan faktor eksternal. Secara teori menurut Ahmad Ifham Sholihin pembiayaaan bermasalah terjadi karena adanya faktor internal dan eksternal baik itu internal perusahaan ataupun internal nasabah. Sedangkan faktor penyebab pembiayaan murabahah bermasalah di BMT Husnul Aulia terjadi karena adanya faktor internal yang berupa kesalahan BMT dalam menganalisis pembiayaan yang akan diberikan, kurangnya Sumber Daya Manusia (SDM), sedangkan faktor eksternal pembiayaan murabahah bermasalahnya yaitu kondisi usaha yang tidak stabil, bencana alam, karakter anggota yang buruk dan inflasi.penyelesaian (Syaripuddin, 2020)

Pembiayaan bermasalah juga terjadi karena lemahnya sistem pengawasan dan pembinaan yang dilakukan BMT Husnul Aulia. Pengawasan dan pembinaan pembiayaan murabahah bermasalah di BMT Husnul Aulia sudah sesuai dengan teori menurut Anang Firmansyah dan Budi W Mahardika bahwa terdapat empat jenis pengawasan. Sedangkan BMT Husnul Aulia mengunakan jenis pengawasan dalam pembiayaan murabahah bermasalah yaitu berdasarkan waktu pengawasannya yang terdiri dari 
pengawasan represif dan pengawasan preventif. Selain melakukan pengawasan, BMT Husnunul Aulia melakukan pembinaan terhadap anggota pembiayaan murabahah bermasalah.

Berdasarkan hasil penelitian bahwasanya pelaksanaan pengawasan dan pembinaan pada pembiayaan murabahah bermasalah di BMT Husnul Aulia Ciledug sebenarnya sesuai dengan teori yang ada. Hanya saja pelaksanaan pengawasan dan pembinaan yang dilakukan kurang optimal. Dikatakan kurang baik karena dilihat dari sisi rasio NPF di BMT Husnul Aulia pada tahun 2018 yaitu sebesar 10\% dimana rasio NPF sebesar 10\% ini BMT tersebut dikategorikan kurang sehat.(Amanah, 2019)

Pengawasan dan pembinaan bermasalah pada BMT Husnul Aulia dikatakan kurang baik juga salah satunya karena adanya kendala-kendala dalam menjalankan fungsi pengawasan dan pembinaan tersebut. Kendala yang dihadap BMT Husnul Aulia dalam menjalankan fungsi pengawasan dan pembinaan pembiayaan murabahahantara lain kurangnya jumlah Sumber Daya Manusia (SDM) karena dari tahun ke tahun pembiayaan murabahah selalu mengalami peningkatan maka tidak semua anggota mendapat pengawasan dan pembinaan tersebut. (Nurkhaerani, 2020)

Selain itu penulis melihat bahwa sistem pengawasan dan pembinaan yang dilakukan BMT Husnul Aulia kurang baik karena perlakuan untuk anggota pembiayaan bermasalah diberlakukan sama seperti halnya anggota pembiayaan lancar. Artinya tidak ada perlakuan khusus untuk pengawasan dan pembinaan pada pembiayaan bermasalah.

Pembiayaan bermasalah merupakan suatu permasalahan yang umum terjadi pada lembaga keuangan baik lembaga keuangan bank maupun lembaga keuangan non-bank. pembiayaan bermasalah dapat dihindari dengan menerapkan kebijakan penyelesaian dalam pembiayaan bermasalah secara baik. Menurut teori yang ada yaitu A. Wangsawidjaja, pembiayaan bermasalah dapat diselesaian dengan melalui recheduling, resstrukturing, dan reconditioning. ). (Yasin \& Muhammad, 2020) Dalam aplikasinya BMT Husnul Aulia melakukan penyelesaian pembiayaan murabahah bermasalah dengan cara penagihan secara intensif, surat teguran yang terdiri dari tiga macam surat teguran. Surat teguran ini merupakan langkah tertulis dari BMT kepada anggota pembiayaan murabahah bermasalah. selain itu BMT Husnul Aulia melakukan penyelesaian pembiayaan murabahah bermasalah yaitu dengan cara rescheduling (penjadwalan ulang) baik jumlah margin maupun jangka waktu jatuh tempo. Dan yang terakhir yaitu BMT Husnul Aulia menyelesaikan pembiayaan murabahah bermasalah dengan penyisihan piutang (PPAP). (Damayanti, 2020)

Dalam melakukan penanganan pembiayaan murabahahbermasalah, BMT Husnul Aulia sejauh ini belum menerapkan eksekusi jaminan. Alasannya karena BMT Husnul Aulia sangat menerapkan prinsip-prinsip syariah dan prinsip kekeluargaan

\section{Kesimpulan}

1. Pelaksanaan pengawasan preventif pembiayaan murabahah bermasalah di BMT Husnul Aulia yaitu dengan melakukan pengecekan administratif pembiayaan atau berkas-berkas persyaratan dan melakukan analisis 6C.

2. Pelaksanaan Pengawasan Represif pada Pembiayaan Murabahah Bermasalah di KSPPS BMT Husnul Aulia Ciledug dengan melakukan pengawasan baik secara langsung ataupun tidak langsung. Pengawasan langsungnya yaitu dengan melakukan kujungan secara rutin ke tempat usaha anggota. Sedangkan pengawasan tidak langsung yaitu dengan melakukan cekling nominatif.

3. Sedangkan pembinaan terhadap anggota pembiayaan bermasalah yaitu dengan melakukan pendampingan-pendamping pihak BMT kepada anggota tersebut. Dalam hal ini BMT lebih berperan sebagai konsultan terkait permasalahan yang sedang dihadapi anggota. 


\section{Daftar Pustaka}

Amanah, Tuty. (2019). Pengaruh Produk Domestik Bruto, Inflasi, Bi Rate, Dan Nilai Tukar Rupiah Terhadap Pembiayaan Bermasalah Dalam Perspektif Ekonomi Islam. Raden Intan Repository, 53(9).

Anugrah, Y. D. Y. (2020). Analisis Konsep Penerapan Pembiayaan Murabahah pada Perbankan Syariah. Muhasabatuna : Jurnal Akuntansi Syariah, 2(2). https://doi.org/10.54471/muhasabatuna.v2i2.806

Cicik Mutiah, Wahab, \& Nurudin. (2020). Pengaruh Pembiayaan Jual Beli, Bagi Hasil, dan Pembiayaan Bermasalah Terhadap Kinerja Keuangan. Jurnal Ilmu Perbankan Dan Keuangan Syariah, 2(2). https://doi.org/10.24239/jipsya.v2i2.33.221-241

Damayanti, S. (2020). Profitabilitas: Dampak Dari Pembiayaan Bermasalah Dan Pendapatan Margin Murabahah. Akurat Jurnal IImiah Akuntansi, 11(3).

Falihah, L., Abrini, R. P., \& Paraya, E. P. (2020). FUNGSI PENGAWASAN OLEH LEMBAGA OTORITAS JASA KEUANGAN TERHADAP SEKTOR PERASURANSIAN DITINJAU DARI HUKUM PENGAWASAN. Jurnal Fundamental Justice, 1(2). https://doi.org/10.30812/fundamental.v1i2.893

Ghozali, M., \& Roficoh, L. W. (2018). Kepatuhan Syariah Akad Murabahah Dalam Konsep Pembiayaan Pada Perbankan Syariah Di Indonesia Mohammad. News.Ge.

Harahap, S. A. R., \& Ghozali, M. (2020). Peran Baitul Mal Wa Tamwil (BMT) dalam Pengembangan Ekonomi Umat. HUMAN FALAH: Jurnal Ekonomi Dan Bisnis Islam, 7(1).

Latif, C. A. (2020). PEMBIAYAAN MUDHARABAH DAN PEMBIAYAAN MUSYARAKAH DI PERBANKAN SYARIAH. AKSY: Jurnal Ilmu Akuntansi Dan Bisnis Syariah, 2(1). https://doi.org/10.15575/aksy.v2i1.7857

Lestari, U. P., \& Jayanti, F. D. (2020). PEMBIAYAAN MURABAHAH PADA PERBANKAN SYARIAH DI INDONESIA. Stability: Journal of Management and Business, 3(1). https://doi.org/10.26877/sta.v3i1.6430

Muhlis. (2020). Penerapan Pembiayaan Murabahah Dalam Perbankan Syariah. Islamic Banking, Economic and Financial Journal, 1(1).

Nasution, S. F. (2021). Pembiayaan Murabahah Pada Perbankan Syariah di Indonesia. AT-TAWASSUTH: Jurnal Ekonomi Islam, 6(1). https://doi.org/10.30829/ajei.v6i1.7767

Nurkhaerani, E. (2020). Penguatan Hukum Baitul Maal Wat Tamwil (BMT) sebagai Lembaga Keuangan Mikro Berbasis Nilai-nilai Islami dalam Mensejahterakan Masyarakat. MUAMALATUNA, 11(2). https://doi.org/10.37035/mua.v11i2.2406

Prastiwi, I. E. (2021). Analisis Kondisi Makro Ekonomi dan Likuiditas terhadap Pembiayaan Bermasalah Perbankan Syariah. Jurnal Disrupsi Bisnis: Jurnal Ilmiah Prodi Manajemen, Fakultas Ekonomi, Universitas Pamulang, 4(1). https://doi.org/10.32493/drb.v4i1.9123

Sari, D. M. S., Suartini, S., Mubarokah, I., \& Hasanuh, N. (2021). Pengaruh Pembiayaan Mudharabah, Musyarakah dan Murabahah Terhadap Profitabilitas Bank Umum Syariah. Jurnal IImiah Ekonomi Islam, 7(1). https://doi.org/10.29040/jiei.v7i1.1850 
Syaripuddin, S. (2020). PENYELESAIAN PEMBIAYAAN BERMASALAH PADA PEMBIAYAAN MURABAHAH DI BANK ACEH SYARIAH TAKENGON. Ihtiyath: Jurnal Manajemen Keuangan Syariah, 4(1). https://doi.org/10.32505/ihtiyath.v4i1.1402

Taslim, S. A. (2021). Pengaruh Pembiayaan Bagi Hasil terhadap Tingkat Profitabilitas Bank Umum Syariah di Indonesia. Jurnal Akuntansi Indonesia, 10(1). https://doi.org/10.30659/jai.10.1.97-109

Tryana, A. L. (2021). Pengaruh Pembiayaan Mudharabah, Pembiayaan Musyarakah, dan Non Performing Financing Terhadap Profitabilitas Bank Umum Syariah 2016-2019. Journal of Accounting, Finance, and Auditing, 3(1).

Ulpah, M. (2020). Strategi penyelesaian pembiayaan bermasalah pada bank syariah. Madani Syari'ah, $3(10)$.

Wahyu, A. R. M., \& Anwar, W. A. (2020). Dewan Pengawasan Syariah Pada Bank Syariah (Tinjauan UndangUndang Perbankan Syariah). Al-Azhar Journal of Islamic Economics, 2(2). https://doi.org/10.37146/ajie.v2i2.44

Yasin, R. M., \& Muhammad, R. (2020). STRATEGI PENYELESAIAN PEMBIAYAAN BERMASALAH: TINJAUAN ASPEK HUKUM (Studi Pada BPRS di Provinsi Daerah Istimewa Yogyakarta). HUMAN FALAH: Jurnal Ekonomi Dan Bisnis Islam, 2(7). 
Siti Fatimah dan Toto Suharto

Banco, Volume 2, Mei 2020 